\title{
Prevention and rehabilitation in the context of long-term care (LTC) in Slovenia
}

\author{
Tatjana Pokrajac \\ University of Ljubljana, Medical faculty, Ljubljana, Slovenia \\ Tatjana.pokraja@@mf.uni-lj.si
}

\section{Abstract}

Introduction: Our work is a more extensive overview of the state of longterm care in Slovenia, describing existing social and health care, and preventive and rehabilitation services in the context of long-term care. Methods: A systematic review of the literature in that bibliographic COBISS database was used. The restrictive criteria were as follows: the literature was summarised from 2010 to 2020 , the authors included in the field of public health, title, summary and content containing content on long-term care. The key words for the search were „elderly“, „demography“ AND „elderly“, „long-term care“ AND „elderly“, „culture“ AND „elderly“, „prevention“ AND „elderly“, „prevention“ AND „longterm care“, „rehabilitation“ AND ”elderly”, „rehabilitation“ AND „longterm care“, „government“ AND „long-term care“, and „funding“ AND „long-term care“. The systematic review was carried out according to the Prisma (Preferred Reporting Items for Systematic Reviews and MetaAnalyses) guidelines. This work is a result of the findings of a European project called INTERLINKS (Engl. INTERfaces and LINKS between prevention, rehabilitation, quality of services and informal care), which deals with health systems and long-term care for older people in Europe. This article is adapted to the situation in Slovenia. Results: The reviewed literature covered 7320 articles, books, laws and results of national statistics, of which 27 were final. The results showed, firstly, that demographic development by 2050 includes both a relative and an absolute increase in older and very old people in Slovenia, and thus we expect an increasing number of people with long-term care needs. We already have a number of activities (e.g. help with personal hygiene at home, community care, social networking, etc.) and various providers (Community nurses, health technicians, social workers, etc.) who deal with issues that are elements of long-term care, but we do not yet have the full scope of this activity and the operators. Legislation on long-term 
care in Slovenia is currently being prepared at national level. Currently, activities are financed from a number of sources: central budget, municipal budget, direct payments and other sources such as voluntary contributions, grants and sponsorship. Discussion and conclusion: Longterm care in Slovenia is at the beginning of its operation. It is obvious that the system is very complex and fragmented, and still cannot meet all demand. Existing services and benefits are not linked to a single system. We hope that the system will be treated by legislation, a long-term care law, that has already been written and we are waiting for its adoption.

Keywords: demography; community nurse; social workers; home for older people; acute care

\section{Introduction}

Slovenia belongs to the countries with older population. In 2019, the proportion of people older than 65 years amounts to $20 \%$. Among all elderly citizens, the share of women lies at $30.2 \%$. In 2019, the total number of citizens aged 65 and above exceeded the total population from o to 15 years. Life expectancy for men in 2019 is 78.32 years and for women 83.98 years. In 2018, 20485 people died in Slovenia. An average year of death at the moment is 77.9 years. Thus, there will be a significant increase in the proportion of the population older than 80 years. Long-term population projections for 2050 indicate a further increase in the proportion of older people in Slovenia and an increase of $10.6 \%$ of the proportion of the population aged over 80 years (SORS, 2019). Slovenia does not have a single system for long-term care (LTC) for older people, chronically ill, disabled persons, who need partial or full assistance of another person. Instead, there is a variety of services and (cash) benefits providers, in the context of existing social protection systems and medical care (Prevolnik-Rupel, 2010; Toth, 2018). Social Security Act (SSA, 2007-2019) defines the available long-term care services in Slovenia, that are primarily intended for ill, handicapped and older persons. The Government of the Republic of Slovenia has announced a law, which will comprehensively regulate the activity of long-term care and provide a stable revenue collection by introducing a system of social (and voluntary) insurance scheme (GOV RS, 2019).

The aim of this article is to discuss the problems of long-term care in Slovenia, adding the knowledge and practice of prevention and rehabilitation within long-term care in Slovenia and contribute to the discussion and adoption of the Law on long-term care.

\section{Methods}

Descriptive research methodology was used to review peer-reviewed literature about prevention and rehabilitation within long-term care in Slovenia. The systematic review was carried out according to the PRISMA (Preferred Report- 


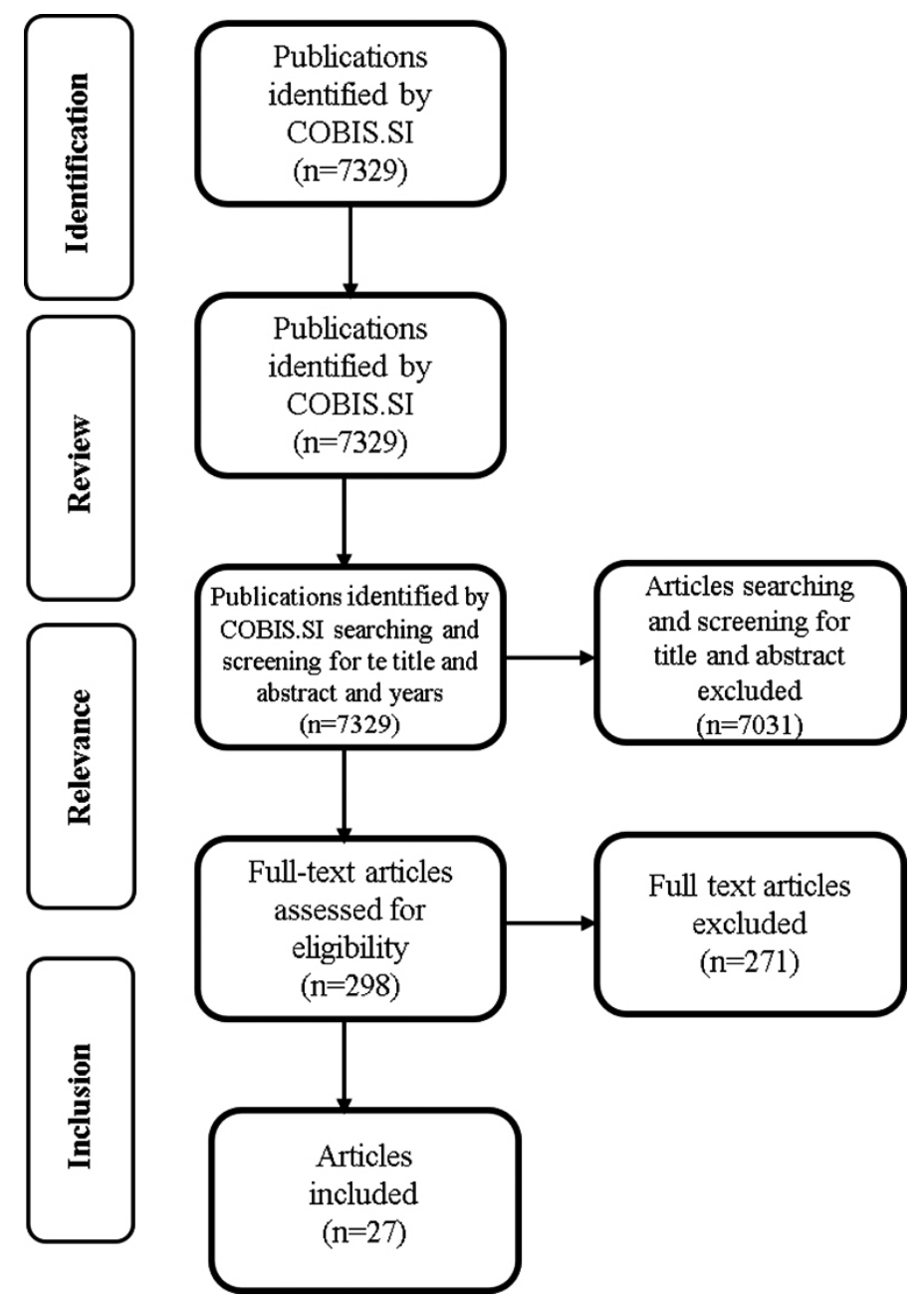

Figure 1: Flow chart of selection of researches

ing Items for Systematic Reviews and Meta-Analyses) guidelines (Welch, et al., 2012).

We searched the literature in the database COBIS.SI system in the period 1st of January 2000 to 30 d of November 2019. I used the search terms: " elderly', ' demography 'AND ' elderly', ' long-term care 'AND ' elderly', ' culture 'AND ' elderly ', ' prevention ' AND ' elderly ', 'prevention 'AND ' long-term care ', ' rehabilitation 'AND ' elderly', ' rehabilitation 'AND ' long-term care ', 'financing 'AND ' long-term care', government AND long-term care.

The websites of national and international organizations were also searched for data reporting long-term care published until 1st January 2010. These websites were selected on a discussion with all study authors including by project INTERLINKS (Kümpers, et al., 2010). Literature from Slovenian and other public health websites: "INTERLINKS", "National Institute of Public 
Level 1

Systematic review randomized clinic researches

$\mathrm{N}=5$

Level 2

Systematic review nonrandomized clinic researches

$\mathrm{N}=0$

Individual nonrandomized studies

$\mathrm{N}=0$

Level 3

Systematic review correlation / observational researches

$\mathrm{N}=4$

Level 4

Individual correlation / observational researches

$\mathrm{N}=0$

Level 5

Systematic review of descriptive / qualitatie / physiological researches $\mathrm{N}=2$

Level 6

Individual review of descriptive / qualitatie / physiological researches $\mathrm{N}=0$

Level 7

Opinions of authors, expert commissions

$\mathrm{N}=2$

\section{Figure 2: Hierarchy of evidence}

Health of the Republic of Slovenia" (NIPH RS), The Statistical Office of the Republic of Slovenia (SORS), Health Insurance Institute of Slovenia (HIIS), 2019 and "SHARE" (OECD, 2019). Laws has also been included in the review (CDA, 2006; FC, 2017-2019; PDIA -2, 2012 - 2020; Rules amending the Rules on the immunoprophylaxis and chemoprophylaxis Program for 2009; ReNSAP, 1320, 2013; SAA, 2007-2019).

The inclusion criteria were: the time window of the literatures in Slovene and English from 1st of January 2010 to 3ond of November 2019, qualitative and quantitative and scientific researches and reviews, at least one author was in the field of public health, thematic relevance according to the research area, fully accessible text.

Literature review from system COBISS was used for literature screening based on defined inclusion and exclusion criteria. We identified 7329 hits. We 
didn't have duplicates. We examined the hits for the title and abstracts and excluded $n=7031$ articles. Number of 271 full text articles are excluded. 27 hits corresponded to the inclusion criteria for the final analysis (Figure 1).

Evaluation of the quality of the review and description of data processing the quality of the literature review was determined by the example of Polita and Becka (Polita \& Becka, 2008). Two articles were based on a randomised clinical trial, four were based on a systematic review of correlation observation researches, one article was systematic review of descriptive/qualitative/physiological study and one was based as opinions of authors, expert commissions. The other articles were lower in terms of the hierarchy of evidence (Figure 2).

\section{Results}

We researched four sections within long-term care (prevention, rehabilitation, government and financing). The reason was, that the research is the part of the project of INTERLINKS which covered upper mentioned fields but is adopted on Slovenian environment. The characteristics of the individual scientific section included in the analysis are shown in Table 1 . Results are the principle of qualitative content analysis.

Table 1: A review of the key findings of the research included in qualitative content analysis

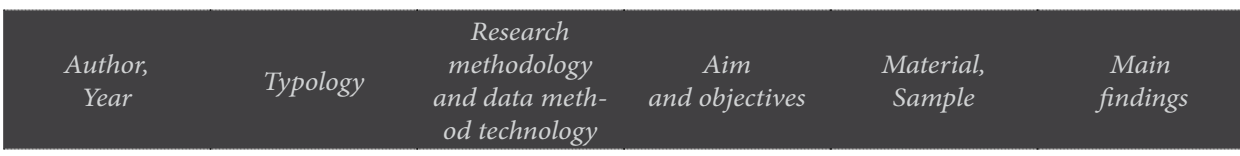

Cultural and political topics within LTC discourses in Europe; Governance: Col-

Descriptive vignettes; an EU quick-scan literature review;

Kümpers, et al., Project INTER2010 LINKS
Important thread in public and political debates focuses on the potential of prevention and rehabilitation for older people in European Union focus group discussions with the national Expert Panels and descriptive, national state of the art reports laboration versus competition; Embedding $\mathrm{P} \& \mathrm{R}$ in mainstream services; Embedding $\mathrm{P} \& \mathrm{R}$ in mainstream services; $\mathrm{P} \& \mathrm{R}$ across LTC pathways; Promoting self-determination and self-care in Europe; Special topic: Dementia. 


\begin{tabular}{|c|c|c|c|c|c|}
\hline $\begin{array}{c}\text { Author, } \\
\text { Year }\end{array}$ & Typology & $\begin{array}{c}\text { Research } \\
\text { methodology } \\
\text { and data meth- } \\
\text { od technology }\end{array}$ & $\begin{array}{c}\text { Aim } \\
\text { and objectives }\end{array}$ & $\begin{array}{c}\text { Material, } \\
\text { Sample }\end{array}$ & $\begin{array}{l}\text { Main } \\
\text { findings }\end{array}$ \\
\hline
\end{tabular}

Government

of the Repub-

lic of Slovenia,

2019 Conta-

gious Diseas-

es Act, 2006;

Rules amend-

ing the Rules

on the immu-

noprophylax-

is and chem-

oprophylaxis

Program for

2009, 2009; So- Law

The objective of

the long-Term

cial Assistance

Care Act is goal

to be accepted

Homemaking,

Help with personal hygiene,

Social network-

ing, Vaccina-

tion, Home

nursing (com-

munity nurs-

ing), Gener-

al practitioners

or family doc-

tor duties and

visits, Acute

care, history in

Slovenia, sub-

acute care, day

centers, insti-

tutional care,

home care, so-

sion and Disa-

bility Insurance

cial services.

2019. Fami-

ly Code, 2017-

2019

Statistical Of-

fice of the Re-

public of Slo-

venia (SORS),

2011; Statisti-

cal Office of the

Republic of Slo-

venia (SORS), National

2019; Outpa-

tient health-

care activities

(OHA) 2019;

Health Statis-

tical Yearbook,

2017; Hlebec,

2018 statistic

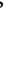

\begin{tabular}{|c|c|c|c|}
\hline $\begin{array}{l}\text { National } \\
\text { statistic }\end{array}$ & I & $\begin{array}{l}\text { Demographic } \\
\text { changes, num- } \\
\text { ber of home as- } \\
\text { sistance, num- } \\
\text { ber of nurses, } \\
\text { number of pre- } \\
\text { ventive visits, } \\
\text { number of cu- } \\
\text { rative visits, } \\
\text { number of so- } \\
\text { cial workers, } \\
\text { number of plac- } \\
\text { es at home for } \\
\text { older people, } \\
\text { number of shel- } \\
\text { tered housing. }\end{array}$ & $\begin{array}{l}\text { Slovenian pop- } \\
\text { ulation, } \\
\text { people older } \\
\text { than } 65 \text { years, } \\
\text { leaving in Slo- } \\
\text { venia, random } \\
\text { sample, as at } \\
\text { 3ond of June } \\
\text { the same year }\end{array}$ \\
\hline
\end{tabular}

Demographic

changes, num-

ber of home as-

ce, num -

number of $\mathrm{cu}$ -

rative visits,

number of plac-

es at home for

number of shel-

tered housing.
In 2019, the proportion of people older than 65 years amounts to 20\%; In 2017 the number of nurses was 853.55 we had 90.2 per 1000 population preventive visits and 489.2 per 1000 populations curative visits; in 2007 743 social workers carrying out home care; we have around 15.000 places at homes for older people. 


\begin{tabular}{|c|c|c|c|c|c|}
\hline $\begin{array}{c}\text { Author, } \\
\text { Year }\end{array}$ & Typology & $\begin{array}{c}\text { Research } \\
\text { methodology } \\
\text { and data meth- } \\
\text { od technology }\end{array}$ & $\begin{array}{c}\text { Aim } \\
\text { and objectives }\end{array}$ & $\begin{array}{c}\text { Material, } \\
\text { Sample }\end{array}$ & $\begin{array}{l}\text { Main } \\
\text { findings }\end{array}$ \\
\hline
\end{tabular}

\begin{tabular}{|c|c|c|c|c|c|}
\hline $\begin{array}{l}\text { Prevolnik-Ru- } \\
\text { pel et al., } 2010\end{array}$ & $\begin{array}{l}\text { Professional } \\
\text { monograph }\end{array}$ & $\begin{array}{l}\text { Review of the } \\
\text { literature, ob- } \\
\text { servational }\end{array}$ & $\begin{array}{l}\text { Long-term care } \\
\text { in Slovenia }\end{array}$ & $\begin{array}{l}\text { Slovenian pop- } \\
\text { ulation, } \\
\text { people older } \\
\text { than } 65 \text { years, } \\
\text { random sample }\end{array}$ & $\begin{array}{l}\text { Overview of the } \\
\text { system, assess- } \\
\text { ment of needs, } \\
\text { available LTC } \\
\text { services, man- } \\
\text { agement and } \\
\text { organization, } \\
\text { integration of } \\
\text { LTC, funding, } \\
\text { demand and } \\
\text { supply of LTC, } \\
\text { funding, LTC } \\
\text { policy }\end{array}$ \\
\hline $\begin{array}{l}\text { Hvalič Touzery, } \\
2014\end{array}$ & $\begin{array}{l}\text { Original scien- } \\
\text { tific article }\end{array}$ & $\begin{array}{l}\text { Statistics, bivar- } \\
\text { iant analysis }\end{array}$ & $\begin{array}{l}\text { Assessment of } \\
\text { satisfaction of } \\
\text { elderly in Slo- } \\
\text { venia }\end{array}$ & $\begin{array}{l}1306 \text { Slovenian } \\
\text { elderly }\end{array}$ & $\begin{array}{l}\text { The differences } \\
\text { between young } \\
\text { people and } \\
\text { the elderly in } \\
\text { terms of health, } \\
\text { well-being and } \\
\text { life satisfaction. } \\
\text { They found that } \\
\text { self-assessment } \\
\text { of health is as- } \\
\text { sociated with } \\
\text { age. The oldest } \\
\text { old people have } \\
\text { the most symp- } \\
\text { toms of vari- } \\
\text { ous diseases, } \\
\text { difficulty con- } \\
\text { centrating and } \\
\text { lacking ener- } \\
\text { gy and are most } \\
\text { limited in daily } \\
\text { activities. Posi- } \\
\text { tive attitudes to } \\
\text { life with age are } \\
\text { declining. }\end{array}$ \\
\hline
\end{tabular}




\begin{tabular}{|c|c|c|c|c|c|}
\hline $\begin{array}{c}\text { Author, } \\
\text { Year }\end{array}$ & Typology & $\begin{array}{c}\text { Research } \\
\text { methodology } \\
\text { and data meth- } \\
\text { od technology }\end{array}$ & $\begin{array}{c}\text { Aim } \\
\text { and objectives }\end{array}$ & $\begin{array}{c}\text { Material, } \\
\text { Sample }\end{array}$ & $\begin{array}{c}\text { Main } \\
\text { findings }\end{array}$ \\
\hline
\end{tabular}

The use of

(ICT) in the field of longterm care, in particular supply robotics, raises many serious concerns; the main is that the supply service of the robot is imperson-

Assessment of

Ramovš, 2019 Editorial

$\stackrel{ }{\circ}$ information

communica-

tion technology

(ICT) use
Review article al. The con-

cerns and fears are real. ICT is

not an appro-

priate substi-

tute for human

beings because

it embodies in-

ter-human co-

existence and

weakens in hu-

mans the social

immune im-

pulse of soli-

darity.

In Slovenia, the

health services

and social-ac-

tivity, and the

concept of

long-term care

are mixed, and

are not clearly

defined by law

and practice;

There are many

activities and

various con-

tractors, deal-

ing elements of

long-term care.

The long-term

care field is still

not able to cov-

er the needs.

Existing servic-

es and benefits

are not linked

into a single

system. 


\begin{tabular}{|c|c|c|c|c|c|}
\hline $\begin{array}{l}\text { Author, } \\
\text { Year }\end{array}$ & Typology & $\begin{array}{c}\text { Research } \\
\text { methodology } \\
\text { and data meth- } \\
\text { od technology }\end{array}$ & $\begin{array}{c}\text { Aim } \\
\text { and objectives }\end{array}$ & $\begin{array}{c}\text { Material, } \\
\text { Sample }\end{array}$ & $\begin{array}{l}\text { Main } \\
\text { findings }\end{array}$ \\
\hline Turk, 2008 & $\begin{array}{l}\text { Scientific re- } \\
\text { search article }\end{array}$ & Review & $\begin{array}{l}\text { Review of reha- } \\
\text { bilitation pro- } \\
\text { grams }\end{array}$ & $\begin{array}{l}\text { Slovenian pop- } \\
\text { ulation old- } \\
\text { er than } 65 \text { years } \\
\text { (random sam- } \\
\text { ple) }\end{array}$ & $\begin{array}{l}\text { Rehabilitation } \\
\text { measures in } \\
\text { case of injuries, } \\
\text { conic non-com- } \\
\text { municable dis- } \\
\text { eases; surgery, } \\
\text { early medical } \\
\text { rehabilitation, } \\
\text { home care, pal- } \\
\text { liative care }\end{array}$ \\
\hline $\begin{array}{l}\text { Government of } \\
\text { the Republic of } \\
\text { Slovenia (GRS), } \\
2019 .\end{array}$ & Speech & / & $\begin{array}{l}\text { Given the prob- } \\
\text { lem of frag- } \\
\text { mented and not } \\
\text { the entire sup- } \\
\text { ply of the elder- } \\
\text { ly, the objective } \\
\text { of the long- } \\
\text { Term Care Act } \\
\text { is goal to be ac- } \\
\text { cepted. }\end{array}$ & / & $\begin{array}{l}\text { On a national } \\
\text { level, long-term } \\
\text { car law is cur- } \\
\text { rently in prepa- } \\
\text { ration. }\end{array}$ \\
\hline $\begin{array}{l}\text { Social As- } \\
\text { sistance Act } \\
\text { (SAA)., 2007- } \\
\text { 2019; Health } \\
\text { Insurance In- } \\
\text { stitute of Slo- } \\
\text { venia (HIIS), } \\
\text { 2019; Pension } \\
\text { and Disability } \\
\text { Insurance Act } \\
\text { (PDIA -2), } 2012 \\
\text { - } 2019 . \text { OECD } \\
2018\end{array}$ & Law & / & $\begin{array}{l}\text { How do we } \\
\text { fund LTC ser- } \\
\text { vices? }\end{array}$ & / & $\begin{array}{l}\text { Long term care } \\
\text { in Slovenia is fi- } \\
\text { nanced from } \\
\text { multiple sourc- } \\
\text { es: } \\
\text { central budget, } \\
\text { municipal } \\
\text { budget, direct } \\
\text { payments and } \\
\text { other sources } \\
\text { like voluntary } \\
\text { contributions, } \\
\text { donations and } \\
\text { sponsorship }\end{array}$ \\
\hline
\end{tabular}

\section{Discussions}

According to our results, the article is a review description of the situation of long-term care in Slovenia, the special integration of prevention and rehabilitation within long-term care that would or would be carried out in Slovenia. The results obtained coincided with the results of the pre-European systematic researches (Kümpers et al., 2010).

Community nursing is organized as an independent organizational unit within primary health care institutions. Home visits are effective in reducing mortality, are effective in reducing admission to long-term institutional care/ nursing homes for older people and are effective in improving physical functioning or reducing physical decline in older people. Reference clinics are clinics of family medicine, reinforced by a graduate nurse. It is about strengthening the family medicine team and, he does, basic health activities, which is a health policy priority. In this way, the quality of work and patient satisfaction 
will be improved. The introduction of new staff will also allow for the reallocation of certain tasks and responsibilities (referencna-ambulanta.si/). The current Government wants to re-establish the Institute for gerontology and geriatric and adopted a document "Strategy care for the older by 2010 - solidarity, harmony and quality aging". The resulting gap is partially filled by the work of Institute Anton Trstenjak (http://www.inst-antonatrstenjaka.si/tisk/kakovostna-starost/stevilka.html). In Slovenia, virtually we do not have gerontologic hospital or institute, nor specialization on this field. Instead we have specialization for family doctors. In Slovenia after hospital discharge, many old people continue their treatment in the hospital with non-acute department - department of prolongation hospitalization and nursing department. The institutional care has the longest tradition in Slovenia and is the most spread in all Slovenian regions. Some institutionalized professional settings are performing activities in line of standards and procedures ISO 9001:2008 and E-Qualin (Prevolnik-Rupel, 2010).

Old age is marked with multimorbidity and greater frequency of injuries. Most common injuries are shaft fractures, osteoporotic vertebra fractures and hip fractures. Those decrease functional abilities and daily living quality. The current treatment for injuries include surgery, early medical rehabilitation and home care. Degenerative diseases, chronic diseases, diabetes, cerebrovascular diseases (CVD), arteriosclerosis, and osteoporosis, require a special form of rehabilitation, from early medical rehabilitation, immediately after the cerebrovascular insult, throughout to verticalization, spa treatment and home care. Oncological patients and palliative care for older people require special attention in the rehabilitation program. Artists are physiotherapists, occupational therapist and community nurses (Turk, 2010).

In the policy area on national level a law regarding long-term care are now in preparation stages for legislation (Prevolnik-Rupel, 2010).

According to the Social Security Act (UL 3/07) these sources are central budget, municipal budget, direct payments and other sources like voluntary contributions, donations and sponsorship money (Prevolnik-Rupel, 2010). A detailed estimation of expenditure for prevention and rehabilitation in LTC cannot be performed at the moment.

\section{Conclusions}

In Slovenia, health preventive measures in home environment are carried out by community nurses and GP/family doctors. GP/family doctors carry out the primary and secondary prevention of chronic non-communicable diseases. In 2007,743 social workers carried out social welfare measures. Rehabilitation services at home are almost not organized.

The rate of hospital treatment of older people in Slovenia is still growing. Non-acute hospitals have been operating for several years. Hospitals with departments of prolonged hospital treatment and nursing departments are be- 
ing implemented. The main task of non-acute departments is rehabilitation or continuation of rehabilitation, which the patient has already started on the sick ward. Daily centers are also undergoing preventive and rehabilitation programs: promoting healthy lifestyle, health education about diseases, exercises, working therapy, etc. In acute and non-acute hospitals social workers carry out organization of home environment, assisting in organizing the additional support at home or assist the installation of the older persons in the social security institutes.

\section{References}

CINZIA HROBAT, N., 2020. Zakonodaja in financiranje kot omejitve na področju razvoja oskrbovanih stanovanj:master thesis [on line]. Nova Gorica: FDŠ - Nova Univerza.

Fakulteta za državne in evropske študije [viewed 10. October 2020]. Available at: http://revis.openscience.si/info/index.php/slo/.

Contagious diseases act, 2006. Gazette of the Republic of Slovenia no. 33/2006.

Family code, 2017-2019. Official gazette of the Republic of Slovenia, no. 15, 21, 22/2017-2019.

Government of the Republic of Slovenia, 2019. Dolgotrajna oskrba. [on line]. [viewed 23. November 2019]. Available:at:https://www.gov.si/podrocja/ zdravje/dolgotrajnaoskrba/.

GovernmentoftherepublicofSlovenia,2019.PredlogZakona odolgotrajnioskrbi. [online]. [viewed 23. November2019].Availableat:https://www.google.com/ search?ei=slbZXabCBazokgWW9Yf4 BA\&q=predlog+zakona + o + dolgotrajni+oskrbi\&oq=Predlog+Zakona+o+dolgotrajni+oskrbi\&gs_l=psy-ab.1.o.oi19l2joi22i3oi19.4707.4707..6628...o.o..o.103.103.0j1..........2j1.. gws-wiz.c6lLvJ7ymG8\#spf=1574527214765].

Health insurance institute of Slovenia, 2019. Systems of Funding the Health Care Activities. [on line]. [viewed 23. November 2019]. Available at: http:// www.zzzs.si/index.html

HVALIČ TOUZERY, S., 2014. Zdravje, počutje in zadovoljstvo z življenjem najstarejših starih v Sloveniji. Teorija in praksa, vol. 51, no.2-3, pp. 458-474.

KÜMPERS, S., ALLEN, K., CAMPBELL, L., DIETERICH A., GLASBY. J., KAGIALARIS, G., et al., 2010. Prevention and rehabilitation within longterm care across Europe. Berlin, Copenhagen, Vienna: European Centre for Social Welfare and Research..

National institute of public health of the Republic of Slovenia, 2017. Health Statistical Yearbook. Ljubljana: NIJZ. [on line]. [viewed 10. 11. 2017]. Available at: http://www.zzzs.si/index.htmlAvailable at: https://www.nijz.si/sl/ publikacije/zdravstveni-statisticni-letopis-slovenije-2017. 
National institute of public health of the Republic of Slovenia, 2019. Zdrav življenjski slog. [on line]. [viewed 23. November 2019]. Available at: https:// www.nijz.si/sl/search/node/zdrav\%20\%C5\%BEivljenjski\%2oslog

National institute of public health of the Republic of Slovenia, 2019. Outpatient healthcare activities (OHA) 2019. [on line]. [viewed 23. November 2019]. Available at: https://www.nijz.si/sites/www.nijz.si/files/uploaded/podatki/podatkovne_zbirke_raziskave/zubstat_szbo/mn_kadri_in_ ure_2019_kon_a.pdf

OECD (EU), 2018. Health at a Glance: Europe 2018: State of health of the EU cycle. Paris: OECD Publishing, pp. 204. [on line]. [viewed 10. November 2018]. Available at: https://doi.org/10.1787/23056088

OECD (EU), 2019. Health at a Glance: Europe 2019; OECD Indicators. Paris: OECD Publishing. [on line]. [viewed 10. November 2019]. Available at: https://doi.org/10.1787/4dd50co9-en.

Pension and disability insurance act, 2012 - 2019. Official Gazette of the Republic of Slovenia, no. 96/12, 39/13, 99/13, 101/13, 44/14, 85/14, 95/14, 90/15, 102/15, 23/17, 40/17, 65/17 and 28/19 (2012-2019).

POLIT, D.F. and BECK, C.T. 2008 Nursing Research, Generating and Assessing Evidence for Nursing Practice. 8th ed, Philadelphia: Wolters Kluwer Health/Lippincott Williams \& Wilkins.

PREVOLNIK-RUPEL, V. and MAJCEN, B., 2010. Long term care system in Slovenia. Brussels: European Network of Economic Policy Research Institutes.

Referenčne ambulante družinske medicine. Referenčne ambulante družinske medicine.[on line]. [viewed 23. November 2020]. http://www.referencna-ambulanta.si/

Rules amending the rules on the immunoprophylaxis and chemoprophylaxis. program for 2009, 2009. Official Gazette of the Republic of Slovenia no. 24, 36/2009.

RAMOVŠ, J., 2019. Za kakovostno staranje in lepše sožitje med generacijami. Ljubljana: Inštitut Antona Trstenjaka za gerontologijo in medgeneracijsko sožitje.

Resolution on the national social assistance program 2013-2020. Official Gazette of the Republic of Slovenia no. 39/2013.

Social assistance act., 2007-2019. Official Gazette of the Republic of Slovenia, no. 3/o7, 23/07, 41/07, 61/10, 62/10, 57/12, 39/16, 52/16, 15/17, 29/17, 54/17, 21/18, 31/18and 28/19/2007-2019.

Statistical office of the Republic of Slovenia, 2011. The elderly in Slovenia. Ljubljana: Narodna in univerzitetna knjižnjica.

Statistical Office of the Republic of Slovenia (SORS), 2019. Novo v podatkovni bazi SiStat: Prebivalstvo, [on line]. [viewed 1. July 2019.]. Available at: https://www.program-svit.si/1. julij 2019. Available at: https://www.stat. si/StatWeb/News/Index/8498. 
TOTH, M., 2018. Dolgotrajna oskrba, kot nova in posebna veja socialne varnosti. Socialni izziv, vol. 23, no. 39, pp. 44-46.

TURK, Z., JESENŠEK PAPEŽ, B., TURK, E., 2008. Specifičnost rehabilitacije starostnikov. Zdravniški Vestnik, vol. 77, pp. 833-838.

World health organization, 2019. Nursing. [on line]. [viewed 23. November 2019.]. Available at: https://www.who.int/topics/nursing/en/

WElCH, V., PETTICREW, M., TUGWELl, P., MOHER, D., O`NEILL, J., WATERS, E., ET AL., 2012. PRISMA-Equity 2012 Extension: reporting Guidelines for systematic reviews with a focus onhealth equity. Public Library of Science Medicine, vol. 9, no.10. Availabke at; https://doi. org/10.1371/journal.pmed.1001333 